DNA deluge
$\begin{aligned} & \text { Plethora of gene } \\ & \text { patents upsets UK } \\ & \text { ethics council } \\ & \text { p356 }\end{aligned}$

\title{
Geneticist fears 'race-neutral' studies will fail ethnic groups
}

Peter Aldhous

The subject of race in America is a lightning rod that many researchers, especially geneticists, prefer to avoid. But a population

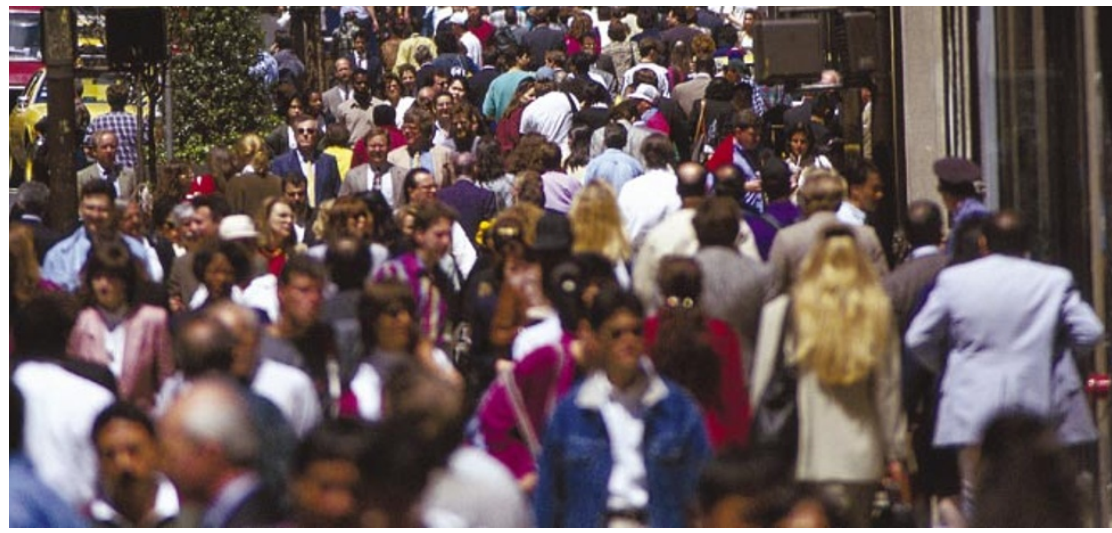

In the mix: geneticists are at odds over whether to divide study populations along racial lines.

\section{Biotech firms spurn university site}

Rex Dalton, San Francisco

Faced with a continuing slump in US financial markets, biotechnology firms are turning down the chance to move into premises on a top university campus.

Nearly 100 researchers at the University of California, San Francisco (UCSF), are set to move into laboratories at the university's new Mission Bay campus in January.

But not a single technology firm has yet signed up to move into the new campus at UCSF, one of the United States' most prestigious biomedical research universities. Plans to construct a laboratory building for such firms are in limbo. An \$85- million commercial office sits vacant on the site, and construction of a second one has been halted.

UCSF officials say that they planned to accommodate professors in buildings adjacent to technology companies to develop "synergies", which they hoped would speed drug development as well as enhancing staff recruitment and retention. geneticist at Stanford University has grabbed it with both hands, claiming that 'colourblind' approaches to medical genetics could actually discriminate against minorities.

But a weak economy, the cost of doing business in San Francisco and the fact that $20 \%$ of the city's offices are vacant seem to have dissuaded firms from moving to Mission Bay.

University officials are putting a brave face on the situation, professing optimism that high-technology tenants will eventually move in. But there is frustration that, after two years of marketing, prospective tenants keep dropping out.

"We are disappointed," says Bruce Spaulding, vice-chancellor for planning at UCSF. "But we remain optimistic — the long-range prognosis is good."

The project's troubles may alarm planners of other schemes in less auspicious locations, including Phoenix, Arizona, and Houston and Dallas, Texas, which have recently announced large investments aimed at attracting biotechnology businesses into close proximity to academic researchers (see Nature 417, 107; 2002).
The geneticist, Neil Risch, claims in a commentary article that political sensitivities may be leading some geneticists to abandon race as a variable in their studies an approach that he thinks is dangerously misguided. "We need to value diversity, not to fear it," Risch and his colleagues argue in the online journal Genome Biology (see http:/genomebiology.com/2002/3/7/ comment/2007). "Ignoring our differences, even with the best of intentions, will ultimately lead to the disservice of those who are in the minority," they say.

Geneticists agree that a diverse population such as that of the United States cannot be considered as a homogeneous group. So, when trying to map the genes that confer susceptibility to particular diseases, or studying the performance of new drugs, it is useful to work out if the population can be divided into subgroups with particular genetic characteristics that might affect the results. One subgroup, for instance, might fail to respond to a drug that works well in the rest of the population.

Some geneticists are therefore studying genetic marker sequences to determine how people cluster into subgroups within the overall population. Last October, for instance, a team led by David Goldstein at University College London used some 40 markers to subdivide a genetically diverse sample of people from various populations throughout the world. They found that the resulting subgroups showed differences in the genes for enzymes that metabolize drugs (see J. F. Wilson et al. Nature Genet. 29, 265-269; 2001). An accompanying editorial praised this "race-neutral" approach to population-genetic studies.

But Risch maintains that self-reported labels of racial origin - such as Caucasian, Asian, African American and Hispanic can do the job just as well as sophisticated gene-clustering studies. "Effectively, you're just going to recreate those racial groups," he argues. What's more, Risch claims, if the data on genetic clustering are collected without regard to race, there is a tendency to assume that differences between the resulting subgroups are due to genetics — when they 
might actually be due to socio-economic or cultural factors that just happen to correlate with race.

Risch also argues that minority groups should be selectively recruited into biomedical studies to ensure that they are sufficiently well represented to reveal any important differences from the population as a whole. Take a race-neutral approach, says Risch, and important information about minority health maybe lost.

Not surprisingly, some scientists take issue with Risch's arguments. Harold Freeman, a prominent African-American researcher who is director of the National Cancer Institute's Center to Reduce Cancer Health Disparities, based in Rockville, Maryland, agrees that cultural factors should be considered in genetic studies. But he argues that racial labels are too crude to be useful. "Culture is not equal to race," says Freeman.

Worse, Freeman fears that the use of race as a variable in biomedical studies will perpetuate historical discriminatory attitudes. He adds that statistical findings from population-genetic studies may be wrongly applied to racial groups as a whole. If a drug is found to work less well in African Americans than in Caucasians, for example, it may end up being denied to individuals within the black population who might nevertheless benefit from it.

Goldstein worries that the tone of the Risch paper will bring unwanted political overtones into what ought to be a technical discussion. He accepts that it can be useful to divide populations into subgroups that reflect the geographical origins of their members' ancestors. However, Goldstein says that "race is not a terribly good framework. I believe we can do better. This is a technical question. I think that Neil has politicized it too much."

Risch argues that his article is merely responding to statements made in the scientific literature by other commentators. For instance, an editorial in The New England Journal of Medicine last year argued that "race is biologically meaningless" (see R. S. Schwartz N. Engl. J. Med. 344, 1392-1393; 2001).

Francis Collins, director of the Nationa Human Genome Research Institute in Bethesda, Maryland, feels that Risch makes some valid points. He points out that the international 'haplotype map' project, an effort to discover disease-susceptibility genes (see Nature 412, 105; 2001), includes DNA samples from the main geographical areas of the world. But Collins thinks that Risch was unwise to frame the issue in terms of racial labels. "It's open to broad misinterpretation," he says. "I'd be happier if we could get away from the highly charged terminology of race and refer instead to geographical origin of ancestors."

\section{Bioethics council demands tighter rules on gene patents}

\section{David Adam, London}

Patents on DNA sequences are granted too easily, too often and with too little scrutiny, says an investigation into gene patenting by Britain's foremost bioethics body.

Thousands of recent patents asserting rights over DNA sequences are of "doubtful validity", according to a report released on 23 July by the Nuffield Council on Bioethics. The report says that, in future, patents involving DNA sequences should be issued as an exception, not as a rule.

Sandy Thomas, director of the council which is operated and funded by the UK government's Medical Research Council and two London-based charities, the Wellcome Trust and the Nuffield Foundation — says the assessment is the broadest attempt yet to take stock of gene patenting after what she terms the "gold rush" that followed the publication of the human genome sequence last year.

"We are concerned that, for patents involving DNA, the patent system is in danger of not achieving its main goal: to stimulate innovation for the public good," Thomas says. Technology that allows computer users to identify genes and then patent them by merely sifting published sequences makes a mockery of the idea that applicants should demonstrate "inventiveness", she argues.

Previously, researchers had to identify, isolate and clone a gene before deciphering its sequence. "We're talking about a reassessment of the system," Thomas says, "not just a little bit of tightening here and there."

The report's authors hope their work will help to inform the decision-making processes of patent offices around the world. Some fear that existing patent regimes are too heavily influenced by pressure from patent applicants and their employers, and are not responsive enough to the interests of other researchers, who want open access to gene sequences, or of society as a whole.

To obtain a patent, applicants must convince patent offices that their innovation is not only novel and inventive, but also useful. The Nuffield report argues that, in many cases, the rigorous application of these existing criteria would reduce the number of gene patents issued, without any new rules.

The world's three largest patent systems, in Japan, Europe and the United States, currently treat each criterion differently. The US patent office is generally the most relaxed in issuing patents that involve DNA sequences, although it has tightened its scrutiny of utility in response to criticism that it was awarding patents on sequences with unproven or purely speculative uses (see Nature 403, 3; 2000).

Rainer Moufang, a patent lawyer with the

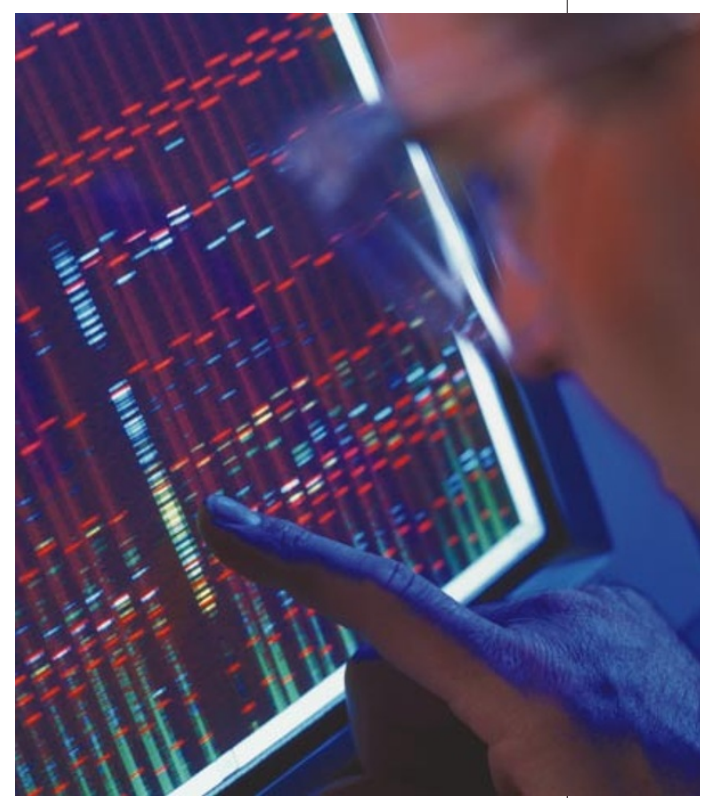

Market speculation: has the availability of the human gene sequence led to a gold rush?

European Patent Office in Munich, says that European regulations have also been tightened and that applicants must show a commercial application before a patent is granted. The report's conclusion that patents on DNA should be the exception rather than the rule is "rather a difficult prognosis", says Moufang. "For us to change our practice we would need a clear hint from legislators," he adds.

Applications for patents on gene sequences that could be used to diagnose diseases should receive particular scrutiny, the report says. It contends, for example, that patents held by the US company Myriad Genetics on the BRCA1 gene, which is linked to susceptibility to breast cancer, give the company effective control over the sequence, stopping others from developing alternative diagnostic tests. Some of Myriad's European patents are being challenged by French researchers (see Nature 413, 95; 2001).

Deryck Beyleveld, director of the Sheffield Institute of Biotechnological Law and Ethics at Sheffield University, UK, welcomes the report's suggestions. "They are workable in both principle and practice," he says. "The obstacles will appear when they run into the politics."

Political leaders associate patents with competitiveness, says Beyleveld, and will be reluctant to discourage gene patenting. "We no longer have a patent system that rewards inventors for their creativity," he claims, "but one that essentially rewards investors for their investment." 